\title{
Legal Analysis of Substance and Implementation of Biased Regional Regulation of Human Right in South Sulawesi Province
}

\author{
$1^{\text {st }}$ Hasnawi Haris \\ Departemen of Pancasila and Civic \\ Education \\ Faculty of Social Science \\ Universitas Negeri Makassar \\ Makassar, Indonesia \\ hasnawi.haris@unm.ac.id
}

\begin{abstract}
The aim of the research is to find out the regulation bias against the application of government regulations on human rights. This study uses a qualitative approach that analyzes local regulations that are policies at the district and provincial levels in South Sulawesi Province. From this approach, normative descriptive will be carried out to see a systematic description of the normative and factual regional regulations. Data analysis techniques used are interview, observation and documentation techniques. The results of the study show that: 1) the regional regulations that have been made tend to be biased towards the application of human rights. Likewise: regional regulations in the Pangkep, Bulukumba and Palopo Regencies regarding the application of Human Rights that do not include Law No. 39 of 1999 concerning Human Rights as the basis for implementing the regulation; 2) there are still regulations that do not involve the public either from the aspect of involvement in the formulation of regional planning regulations; 3 ) there is no external institution that monitors every regulation that will be planned, or at the stage of implementing regional regulations; 4) still lacks socialization of the regional regulations that have been made.
\end{abstract}

Keywords - Content, Implementation, Regional Regulation, Bias on human rights

\section{INTRODUCTION}

The beginning of Act Number 39 the Year 1999 on Human Rights and Act Number 26 the Year 2000 on Human Rights Court at the time of the Reformation was the legal and political commitments of the Government in the process of enforcement of human rights in Indonesia which need to get positive appreciation from all components of the Nation. Because the process of enforcement of human rights in Indonesia faced many obstacles both from Regulation aspect (legal rule) as well as non-legal aspect. On legal aspects, for example, though there have been two acts which are Act Number 39 the Year 1999 and Act Number 26 the Year 2000, in fact, these acts still have some disadvantages, especially on substance aspect. On non-legal aspect, the law enforcer behavior hasn't fully supported the process of human rights enforcement. While the culture of law society is also not fully become a good stimulus to the process of human rights enforcement [1]-[5].

Human rights are legal rights possessed by humans on this earth [6]-[9]. The rights obtained in the form of comprehensive matters that are owned by all groups such as: rich and poor, men and women, have high and low social strata. However, these rights are sometimes violated, but will not be abolished. Human rights are legal rights, this means that the rights of a country are based on applicable law. Of course, there are rules both implied and explicit, both at the local, national and international levels. Human rights are things that are acquired from birth which is a gift from God. Human rights are actually upheld, respected and protected by a country, government, law and everyone.

The substance matter and human rights enforcement (implementation) in various regulation including Regional Regulation should not be separated with the direction of Indonesia's legal policy. Legal policy is a direction of legal development which based on the national legal system to achieve the objectives and goals of the country, society, and nation. Law in Indonesia should refer to the ideals of the society, i.e. democratic and social justice of law enforcement. Legal development should be aimed to ended unjust social order and human right repression; therefore legal policy must be oriented on the rule of law which is based upon the principles of democracy and social justice in a unified society of Indonesia, as stated in the Preamble of Constitution 1945 [10].

Regional Regulation is a Legislation rule that is formed from the Regional People's Legislative Assembly through mutual agreement of the Regional Head, either the governor or regent / mayor) [11]-[17]. the regulation in question is a Regional Regulation consisting of: Regional Regulations at the Provincial level as well as Regional Regulations at the District / City level.

Regional Regulations (Perda) as a legal product that has regulated in Act Number 12 the Year 2011 on Regulations Establishment have an urgent and strategic position in 
applying the values of human rights. One of the constraints is the limited knowledge and experience of the regional legislature (DPRD Tingkat I and DPRD Tingkat II) in generating or compiling regional regulations. At this point, it takes in-depth and comprehensive analysis.

Based on the review of the literature and empirical experience it turns out there are a few regional regulations that indicated violate human rights (bias) because the typology of the regional regulations is repressive.

Based on problems identification, the research problem formulation is (i) normative standard measurement in assessing regional regulation that is biased OF human rights, (ii) the implementation of a form of regional regulations that bias of human rights.

\section{RESEARCH METHODS}

The location of this research is in South Sulawesi Province, with sample locations in Bulukumba Regency, Palopo Municipality, and Pangkep Regency. This a normative-descriptive research that aims to make a systematic description of the regional regulations that are normative and factual [18]-[20]. The technique to obtain data (legal material) in this research are documentation of several regional regulations (province-district/city) that has ever been issued to regional government and to analyzed on the normative and empirical basis. Data obtained through indepth interviews with a legal expert during the process of regional regulation legal drafting also with another stake holder. Furtherly, the legal material that have been obtained were analyzed using qualitative normative descriptive analysis [21].

\section{RESULTS AND DISCUSSION}

Reformation in Indonesia on one side recognized the offer of freedom so as to strengthen the bargaining position of the society (civil society) in conjunction with the state. One of the most prominent freedom in this context, it is the discretion of the society through democratic political institutions producing regional regulations which by many party rated as a form of carrying the identity of religion in public space. This theme becomes increasingly interesting, if then be correlated with the principle of Rule of Law in democratic state [8], [22], [23].

Legal policy contains two sides that are inseparable, which are referrals of the making of law or legal policy of State institutions in making laws, and tools to assess and scrutinize whether the law are properly made according to legal policy framework to achieve the State goals.

The Constitution of 1945 stated that Indonesia is a Legal State (rule of law). Social science expert, seeing that the protection of human rights is one of the element of the rule of law, in addition to fair law. We can trace the roots of the principles of the rule of law from jurisprudence of international court such as European Human Right Court, and United Nation of Human Right Committee, to find out and measure how far the state's position against religion and belief according to the rule of law [24]-[26].

Some law product regarding to human rights in regional regulation are includes (i) TAP MPR XVII Year 1998 on Human Rights, (ii) Act Number 39 Year 1999 on Human Rights, (iii) President's Decision $\mathrm{f}$ the Republic of Indonesia Number 40 Year 2004 of the Human Right National Actions Plan year 2004-2009, (iv) Government Regulations Subtitutes to Act Number 1 Year 1999 on Human Rights Court was later replaced by Act Number 26 Year 2000 on Human Rights Court, (v) Government Regulation of the Republic of Indonesia Number 2 Year 2002 on The Rules of Procedure on Protection of Victim and Witness of Human Right Violation, (vi) Government Regulation of the Republic of Indonesia Number 3 year 2002 on Compensation, Restitution, and Rehabilitation for Victims of Gross Violation of Human Right.

Regional regulations actually have a positive impact on the community. However, in Sulawesi Province the substance of the regional regulations produced tends to be biased towards human rights. This is evidenced by several problems faced in each region such as. : 1) Substance of regional regulations produced, 2) implementation of regional regulations.

\section{A. Substance of regional regulations}

Regulations made by the government should be in accordance with the times. However, it becomes a problem in several regions in South Sulawesi Province. The problems faced are regional regulations in Bulukumba Regency, Palopo Municipality, and Pangkep Regency which relate to the implementation of human rights values in the preface "given" not to put Law Number 39 of 1999 concerning Human Rights as the basis for implementation. Furthermore, the rules for the preparation of regional regulations, namely Government Regulation Number 1 of 2001 and Government Regulation Number 25 of 2004 as legal instruments contain less substance in the obligations of the public involved in the proposed Regional Regulation Draft. In addition, it does not have operational guidelines in implementing each regional regulation [6], [7], [27]-[29].

\section{B. Implementation of regional regulations}

Implementation of regional regulations in these areas, there are various obstacles faced such as: 1) Absence of institutions and resources that specifically implement and monitor the implementation of regional regulations, 2) occurrence of non-conformities related to understanding the contents of regional regulations between the Government and the community; 3) Lack of socialization or dissemination so that local regulations tend to be made quickly, and tend to overlook the conditions of the local community's love. This is relevant to the results of other studies that in the implementation of regulations there are various obstacles such as: incompatibility with the implementation that occurred [9], [30]-[33]. So that people as policy makers will get a bad impact. Therefore, the implementation of the policy must be in accordance with the rules that have been set. 
Various regions in South Sulawesi Province have advanced in the formation of regional regulations. However, there are still many regional regulations that only become a requirement for disbursing budgets and legal documents without any policy implementation. Therefore, the regional regulations that are actually made have an impact on the welfare of the community. One of the efforts carried out in the context of realizing regional regulations that are able to prosper the people is to realize regional regulations that are formed from elements of society in need. Furthermore, efforts are needed to realize these regional regulations, namely by implementing policies that are in accordance with mature planning. In addition, it also involves various groups, such as: government, community, stakeholders. So that the rule is achieved in accordance with the expectations of the community [34]-[37].

\section{CONCLUSION}

Regional regulation drafting in Palopo Municipality, Pangkep Regency, and Bulukumba Regency which the main substance are regarding to implementation and human right enforcement are not fully followed the normative instrument of regional regulation drafting that applied (principle, purpose, juridical technical) so that normatively the regional regulation are biased toward human rights.

A biased implementation of regional regulation toward human rights caused limited understanding of the apparatus of Government and the society; the absence of supervision agencies (control) as an indication of the success of failed application of regional regulation; the culture of the society that tend to be apathetic and unresponsive to changes

\section{ACKNOWLEDGMENT}

Thanks to the Faculty of Social Sciences who have provided financial support for this research. Furthermore, we thank the conference manager who has published this article in line with expectations. So that this article can benefit the wider community.

\section{REFERENCES}

[1] L. M. Sundstrom, "Advocacy beyond litigation: Examining Russian NGO efforts on implementation of European Court of Human Rights judgments," Communist Post-Communist Stud., vol. 45, no. 3, hal. 255-268, 2012.

[2] A. Savelyev, "Legal aspects of ownership in modified open source software and its impact on Russian software import substitution policy," Comput. Law Secur. Rev., vol. 33, no. 2, hal. 193-210, 2017.

[3] C. Paisey dan N. J. Paisey, "Whose rights? Professional discipline and the incorporation of a (human) rights framework: The case of ICAS," Crit. Perspect. Account., vol. 23, no. 1, hal. 17-35, 2012.

[4] S. Venturelli, "Ownership of cultural expression: Speech \& culture in the new intellectual property rights regime of the European Union," Telemat. Informatics, vol. 17, no. 1, hal. 9-37, 2000

[5] C. Miska, I. Szőcs, dan M. Schiffinger, "Culture's effects on corporate sustainability practices: A multi-domain and multi- level view," J. World Bus., vol. 53, no. 2, hal. 263-279, 2018.

[6] C. Pekdemir, "On the regulatory potential of regional organic standards: Towards harmonization, equivalence, and trade?," Glob. Environ. Chang., vol. 50, hal. 289-302, 2018.

[7] A. G. Chofreh, F. A. Goni, dan J. J. Klemeš, "Sustainable enterprise resource planning systems implementation: A framework development," J. Clean. Prod., vol. 198, hal. 13451354,2018

[8] J. R. Hackney, "Law and neoclassical economics theory: a critical history of the distribution/efficiency debate," J. Socio. Econ., vol. 32, no. 4, hal. 361-390, 2003.

[9] A. J. Sinclair, M. Doelle, dan R. B. Gibson, "Implementing next generation assessment: A case example of a global challenge," Environ. Impact Assess. Rev., vol. 72, hal. 166-176, 2018.

[10] V. Kumar, "Negotiating constitutions for political unions," Int. Rev. Law Econ., vol. 31, no. 1, hal. 58-76, 2011.

[11] T. Castelo-Grande, P. A. Augusto, A. Fiúza, dan D. Barbosa, "Strengths and weaknesses of European soil legislations: The case study of Portugal," Environ. Sci. Policy, vol. 79, hal. 66-93, 2018

[12] T. Islam dan J. Ryan, "Chapter 2 - Mitigation Rules and Regulations," T. Islam dan J. B. T.-H. M. in E. M. Ryan, Ed. Butterworth-Heinemann, 2016, hal. 37-68.

[13] H. Li dan J. Lu, "Legislation for early childhood education: A case study of China," Child. Youth Serv. Rev., vol. 86, hal. 32-41, 2018.

[14] A. Daly, "The introduction of data breach notification legislation in Australia: A comparative view," Comput. Law Secur. Rev., vol. 34, no. 3, hal. 477-495, 2018.

[15] R. Ramesh, K. Banerjee, A. Paneer Selvam, A. Lakshmi, P. Krishnan, dan R. Purvaja, "Legislation and policy options for conservation and management of seagrass ecosystems in India," Ocean Coast. Manag., vol. 159, hal. 46-50, 2018.

[16] R. Eschen et al., "International variation in phytosanitary legislation and regulations governing importation of plants for planting," Environ. Sci. Policy, vol. 51, hal. 228-237, 2015.

[17] W. H. Reuter, "When and why do countries break their national fiscal rules?," Eur. J. Polit. Econ., 2018.

[18] A. F. Xavier, R. M. Naveiro, A. Aoussat, dan T. Reyes, "Systematic literature review of eco-innovation models: Opportunities and recommendations for future research," $J$. Clean. Prod., vol. 149, hal. 1278-1302, 2017.

[19] N. Pisani, A. Kourula, A. Kolk, dan R. Meijer, "How global is international CSR research? Insights and recommendations from a systematic review," J. World Bus., vol. 52, no. 5, hal. 591-614, 2017.

[20] G. Orzes, A. M. Moretto, M. Ebrahimpour, M. Sartor, M. Moro, dan M. Rossi, "United Nations Global Compact: Literature review and theory-based research agenda," J. Clean. Prod., vol. 177, hal. 633-654, 2018.

[21] D. Barauskaite, J. Gineikiene, V. Auruskeviciene, B. M. Fennis, M. Yamaguchi, dan N. Kondo, "Eating healthy to impress: How conspicuous consumption, perceived self-control motivation, and descriptive normative influence determine functional food choices," Appetite, 2018.

[22] A. Hadenius dan F. Uggla, "Making civil society work, promoting democratic development: What can states and donors do?," World Dev., vol. 24, no. 10, hal. 1621-1639, 1996.

[23] V. G. Boudreau dan S. E. Nikolov, "Political Theories," L. B. T.E. of V. Kurtz Peace, \& Conflict (Second Edition), Ed. Oxford: Academic Press, 2008, hal. 1657-1670.

[24] L. Li, "Chapter 3 - The Culture of the Rule of Law in Contemporary China," L. B. T.-B. the R. of L. in C. Li, Ed. Elsevier, 2017, hal. 85-143.

[25] G. Gaggioli, "International Humanitarian Law: The legal framework for humanitarian forensic action," Forensic Sci. Int., vol. 282, hal. 184-194, 2018.

[26] C. G. Ngwena, "State obligations to implement African abortion laws: Employing human rights in a changing legal landscape," Int. J. Gynecol. Obstet., vol. 119, no. 2, hal. 198-202, 2012.

[27] L. S. de Oliveira, M. E. S. Echeveste, M. N. Cortimiglia, dan C. G. C. Gonçalves, "Analysis of determinants for Open Innovation implementation in Regional Innovation Systems," RAI Rev. Adm. e Inovação, vol. 14, no. 2, hal. 119-129, 2017.

[28] Z. Jiang, Z. Wang, dan Z. Li, "The effect of mandatory 
environmental regulation on innovation performance: Evidence from China," J. Clean. Prod., 2018.

[29] A. J. B. Greenwood, "The first stages of Australian forest water regulation: National reform and regional implementation," Environ. Sci. Policy, vol. 29, hal. 124-136, 2013.

[30] M. Karunananthan, "Can the human right to water disrupt neoliberal water policies in the era of corporate policy-making?," Geoforum, 2018.

[31] M. B. O. Giupponi dan M. C. Paz, "The Implementation of the Human Right to Water in Argentina and Colombia," Anu. Mex. Derecho Int., vol. 15, no. 1, hal. 323-352, 2015.

[32] P. K. Sarker, M. S. Rahman, dan L. Giessen, "Regional governance by the South Asia Cooperative Environment Program (SACEP)? Institutional design and customizable regime policy offering flexible political options," Land use policy, vol. 77, hal. 454-470, 2018.

[33] R. Langner, S. Leiberg, F. Hoffstaedter, dan S. B. Eickhoff, "Towards a human self-regulation system: Common and distinct neural signatures of emotional and behavioural control," Neurosci. Biobehav. Rev., vol. 90, hal. 400-410, 2018.

[34] M. Zefeng, Z. Gang, X. Xiaorui, S. Yongmin, dan H. Junjiao, "The extension of the Porter hypothesis: Can the role of environmental regulation on economic development be affected by other dimensional regulations?," J. Clean. Prod., 2018.

[35] R. C. Marques, P. Simões, dan F. S. Pinto, "Tariff regulation in the waste sector: An unavoidable future," Waste Manag., vol. 78, hal. 292-300, 2018.

[36] M. A. Apostolache, "Regional Development in Romania - From Regulations to Practice," Procedia Econ. Financ., vol. 8, hal. 3541, 2014.

[37] P. Lei, X. Tian, Q. Huang, dan D. He, "Firm size, government capacity, and regional environmental regulation: Theoretical analysis and empirical evidence from China," J. Clean. Prod., vol. 164, hal. 524-533, 2017. 